Scientia Marina 71(1)

March 2007, 123-128, Barcelona (Spain)

ISSN: 0214-8358

\title{
Seasonal variation in the length structure and reproductive condition of the jumbo squid Dosidicus gigas (d'Orbigny, 1835) off central-south Chile
}

\author{
CHRISTIAN M. IBÁÑEZ ${ }^{1,2}$ and LUIS A. CUBILLOS ${ }^{2}$ \\ ${ }^{1}$ Departamento de Ciencias Ecológicas, Facultad de Ciencias, Universidad de Chile, Casilla 653, Las Palmeras 3425, \\ Ñuñoa, Santiago, Chile. \\ ${ }^{2}$ Laboratorio de Evaluación de Poblaciones Marinas, Departamento de Oceanografía, Facultad de Ciencias Naturales y \\ Oceanográficas, Universidad de Concepción, Casilla 160-C, Concepción, Chile. E-mail: lucubillos@udec.cl
}

\begin{abstract}
SUMMARY: In the area off central-south Chile $\left(34-40^{\circ} \mathrm{S}\right)$, a new period of high abundance of Dosidicus gigas has occurred since 2001. The seasonal changes in length structure and reproductive condition of D. gigas in oceanic and coastal waters are described for the period July 2003 to February 2004. The length structure varied significantly between seasons and zones. In the austral winter, medium-sized, maturing individuals were found in oceanic waters while large-sized mature males and maturing females were present in the coastal zone. In the austral spring, maturing medium-sized and large-sized individuals were observed in the oceanic zone. In contrast, two groups of individuals were observed in the coastal zone: one consisting of small and immature individuals, and one consisting of medium-sized maturing specimens. In the austral summer, only the oceanic zone was sampled, and samples contained small immature and maturing medium-sized individuals. We postulate that the spatial and temporal changes in length structure and reproductive condition of D. gigas off central-south Chile are probably due to the existence of a migratory strategy of the species in the study area.
\end{abstract}

Keywords: Dosidicus gigas, length structure, reproduction, jumbo squid, central-south Chile.

RESUMEN: VARIACIONES ESTACIONALES EN LA ESTRUCTURA POBLACIONAL Y CONDICIÓN REPRODUCTIVA DE LA JIBIA DOSIDICUS gIGAS (ORBIGNY, 1835) EN ChILE CENTRO-SUR. - En el área de Chile central $\left(34^{\circ} \mathrm{S}-40^{\circ} \mathrm{S}\right)$, un nuevo periodo de gran abundancia de Dosidicus gigas ha ocurrido desde al año 2001. En este trabajo, se describe los cambios en la estructura de tamaños y la actividad reproductiva de $D$. gigas en zonas oceánicas y costeras durante el periodo comprendido entre julio del año 2003 y febrero del año 2004. La estructura de tamaños de D. gigas varió significativamente entre estaciones y zonas. En invierno, encontramos un grupo de individuos de tamaño medio con una gran proporción de individuos en maduración en la zona oceánica. Otro grupo de individuos de gran tamaño estuvo presente en la zona costera con hembras en maduración y machos maduros. En primavera, la estructura de tamaños consistió de individuos en maduración medianos y grandes en la zona oceánica. En contraste, en la zona costera se observaron dos grupos de individuos: uno compuesto de individuos pequeños e inmaduros y otro grupo con individuos grandes y en maduración. En verano, sólo se obtuvieron muestras de la zona oceánica, que consistió en individuos pequeños inmaduros y ejemplares de tamaño medio en maduración. Este trabajo postula que la estructura de tamaños de D. gigas en Chile centro-sur se debe probablemente a la existencia de una estrategia migratoria de la especie en el área de estudio.

Palabras clave: Dosidicus gigas, estructura de tallas, reproducción, jibia, Chile centro-sur.

\section{INTRODUCTION}

The jumbo squid, Dosidicus gigas, is one of the most abundant squid in the eastern Pacific Ocean (Nesis, 1970; Nigmatullin et al., 2001; Anderson and Rodhouse, 2001), and also one of the largest marine invertebrates in the Chilean fauna (Schmiede and Acuña, 1992; Fernández and Vásquez, 1995). The geographic distribution of $D$. gigas extends from approximately $40^{\circ} \mathrm{N}$ to $42^{\circ} \mathrm{S}$ in 
the eastern Pacific Ocean (Nigmatullin et al., 2001), and it lives in both oceanic and neritic waters, from the surface down to depths of $1200 \mathrm{~m}$ (Nesis, 1970; Roper et al., 1984; Nigmatullin et al., 2001).

Within the range of distribution, the presence of three population groups of D. gigas has been proposed based on differences in the length structure, size at maturity, and the distribution of abundance related to the geographic separation of groups off North, Central and South America (Nigmatullin et al., 2001). In Peru, two overlapping population groups of D. gigas have been described based on the length structure: one consisting of small and immature individuals, and one consisting of mediumsized maturing specimens (Argüelles et al., 2001; Taipe et al., 2001; Tafur et al., 2001).

In Chile, few studies have described the length structure and reproductive activity of D. gigas. Most of the existing Chilean literature available on the species describes the typical mass strandings that have occurred in coastal areas, and/or the sporadic and short-term pulses in abundance that can be deduced from the catch records (Wilhelm, 1951; Schmiede and Acuña, 1992; Fernández and Vásquez, 1995; Rocha and Vega, 2003; Chong et al., 2005). Off Chile, D. gigas exhibits low-frequency eruptions of high abundance, and this is the reason why Fernández and Vásquez (1995) classified it as an ephemeral fishery. A period of high abundance occurred between 1992 and 1994, and Chong et al. (2005) described some changes in the length composition between winter and spring in 1993 for the north-central coast $\left(29^{\circ} 00^{\prime} \mathrm{S}-32^{\circ} 30^{\prime} \mathrm{S}\right)$.

Recently, a new period of high abundance of $D$. gigas has occurred since 2001 off Chile, with total catch reaching 15121 tons in 2003. Nigmatullin et al. (2001) suggest that irregular seasonal invasions into coastal areas in both the northern (western USA) and southern (central Chile) peripheries of the species' range could be due to active feeding migrations during years of high abundance. However, changes in the length structure could also be due to the reproductive strategy of a local squid population increasing in abundance. In this paper, we present the first results on spatial and seasonal changes in the length structure of D. gigas off Chile $\left(34-40^{\circ} \mathrm{S}\right)$, with notes on their reproductive activity. The length structure is analysed on the basis of opportunistic samples obtained between July 2003 and February 2004 in both oceanic and coastal waters off central-southern Chile. Our objective is

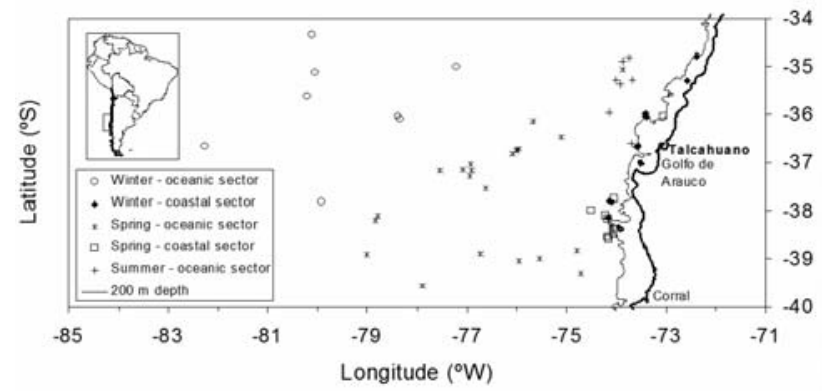

FIG. 1. - Study area, showing the distribution of the fishing sets and towns from which samples of D. gigas were obtained during the study period.

to describe and to compare the size structure and maturation of D. gigas in the coastal and oceanic zones off central-southern Chile during the winter, spring, and summer seasons of 2003-2004, in order to investigate possible migrations associated with squid biology.

\section{MATERIALS AND METHODS}

From July 2003 to February 2004, a total of 268 specimens of $D$. gigas were obtained from the bycatch in the jack mackerel (Trachurus murphyi) purse-seine fishing in oceanic waters at depths of between 25 and $75 \mathrm{~m}$. In addition, 348 specimens were obtained from the industrial trawl fleet fishing for hake (Merluccius gayi), and from the mid-water trawl fleet fishing for Patagonian grenadier (Macruronus magellanicus) close to the continental shelf, mainly near the shelf-slope, at depths of between 120 and $405 \mathrm{~m}$ in the central-south area off Chile $\left(34-40^{\circ} \mathrm{S}\right.$, Fig. 1). The samples were grouped according to austral seasons: winter (JulySeptember), spring (October-December), and summer (January-February) (Table 1).

For all squid, the dorsal mantle length (ML, cm)

TABLE 1. - Number of specimens (n) and range of size (ML) of $D$. gigas by months and sectors.

\begin{tabular}{|c|c|c|c|c|c|}
\hline \multirow[b]{2}{*}{ Year } & \multirow[b]{2}{*}{ Month } & \multicolumn{2}{|c|}{ Oceanic sector } & \multicolumn{2}{|c|}{ Coastal sector } \\
\hline & & $\mathrm{n}$ & ML (cm) & $\mathrm{n}$ & $\mathrm{ML}(\mathrm{cm})$ \\
\hline \multirow{6}{*}{2003} & July & 10 & $(36-60)$ & & \\
\hline & August & 25 & $(45-89)$ & 40 & $(48-91)$ \\
\hline & September & 4 & $(50-60)$ & 39 & $(53-92)$ \\
\hline & October & 39 & $(42-90)$ & 42 & $(48-86)$ \\
\hline & November & 13 & $(54-76)$ & 15 & $(49-74)$ \\
\hline & December & 25 & $(40-88)$ & 212 & $(20-90)$ \\
\hline \multirow[t]{3}{*}{2004} & January & 138 & $(28-84)$ & & \\
\hline & February & 14 & $(35-75)$ & & \\
\hline & Total & 268 & $(28-90)$ & 348 & $(20-92)$ \\
\hline
\end{tabular}


TABLE 2. - Summary of mantle length (ML), body weight (BW), and sex proportion (female:male) of Dosidicus gigas per sector and seasons. Standard deviation is shown in parenthesis.

\begin{tabular}{llccc}
\hline Sector & $\begin{array}{l}\text { Descriptive } \\
\text { statistic }\end{array}$ & $\begin{array}{c}\text { Winter } \\
\text { (July- } \\
\text { September) }\end{array}$ & $\begin{array}{c}\text { Spring } \\
\text { (October- } \\
\text { November) }\end{array}$ & $\begin{array}{c}\text { Summer } \\
\text { (December- } \\
\text { February) }\end{array}$ \\
\hline Coastal & ML (cm) & $72.5(9.1)$ & $54.8(16.1)$ & - \\
& BW (kg) & $14(5.0)$ & $7.2(5.6)$ & - \\
& Sex ratio & $2: 1$ & $2.4: 1$ & - \\
Oceanic & ML (cm) & $54.7(11.1)$ & $61.7(11.6)$ & $43.3(13.0)$ \\
& BW (kg) & $6.6(4.6)$ & $8.9(5.8)$ & $3.4(3.5)$ \\
& Sex ratio & $4.5: 1$ & $2.7: 1$ & $1.3: 1$ \\
& & & & \\
\hline
\end{tabular}

and total weight $(\mathrm{BW}, \mathrm{g})$ were recorded, and the length-weight relationship was established by sex and sector (coastal and oceanic). Maturity stages were identified according to a scale modified from Nesis (1970), Lipinski and Underhill (1995) and Markaida (2001), which recognised four stages (immature, maturing, mature and post-spawning). In some individuals the mantle and reproductive organs were damaged during fishing operations, and therefore the sample size for analysis of maturity was smaller than that for the length-frequency data (see Tables 1 and 2).

The mantle length data were grouped in $5 \mathrm{~cm}$ classes to obtain length-frequency histograms for each sector and season, and for the entire sample. The length-frequency data were compared among sectors according to season using the KolmogorovSmirnov test for paired samples (Zar, 1984). The frequencies of sexual maturity stages were compared between sexes using the log-likelihood ratio for contingency tables ( $\mathrm{G}$ test), and the statistical significance evaluated through chi-square analysis (Zar, 1984). Finally, the maturity stage distribution was pooled according to the mantle length (grouped in $5 \mathrm{~cm}$ classes) by sex for the whole sampled period.

\section{RESULTS}

The length-weight relationships were similar in males and females (Fig. 2), and also for the coastal $\left(a=0.0144, b=3.21, \mathrm{r}^{2}=0.989\right)$ and oceanic $(a=$ $\left.0.0167, b=3.17, \mathrm{r}^{2}=0.978\right)$ sectors. Therefore, the length-weight relationship for both sexes can be expressed by:

$$
B W=0.0151 \times M L^{3.2}
$$

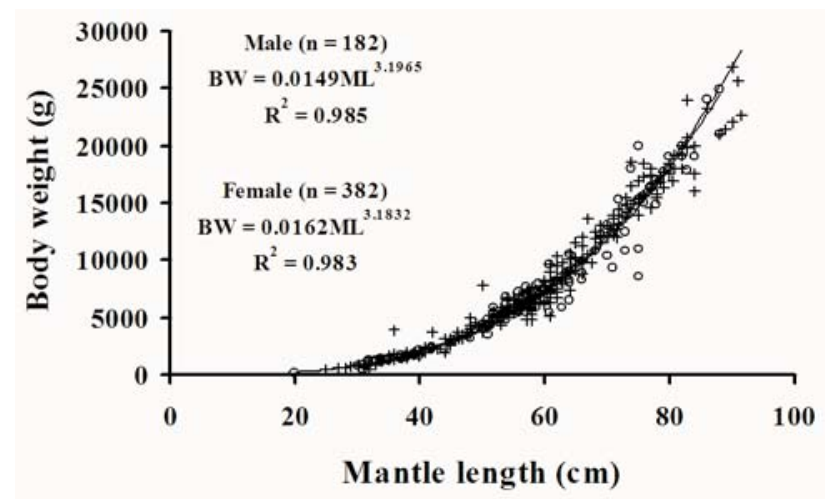

FIG. 2. - Length-weight relationship, by sex, of D. gigas (crosses = male, circle = female).

where $B W$ is the total body weight $(\mathrm{g})$ and $M L$ the mantle length $(\mathrm{cm})\left(\mathrm{r}^{2}=0.986, \mathrm{p}<0.05\right)$.

In winter, 79 individuals of D. gigas were obtained from the coastal sector, consisting of 24 males, 49 females and 6 undetermined (without inner parts). The average length, body weight and sex ratio are shown in Table 2 . Squids were larger than in the oceanic sector (Fig. 3). In the oceanic sector, 39 individuals were collected, consisting of 7

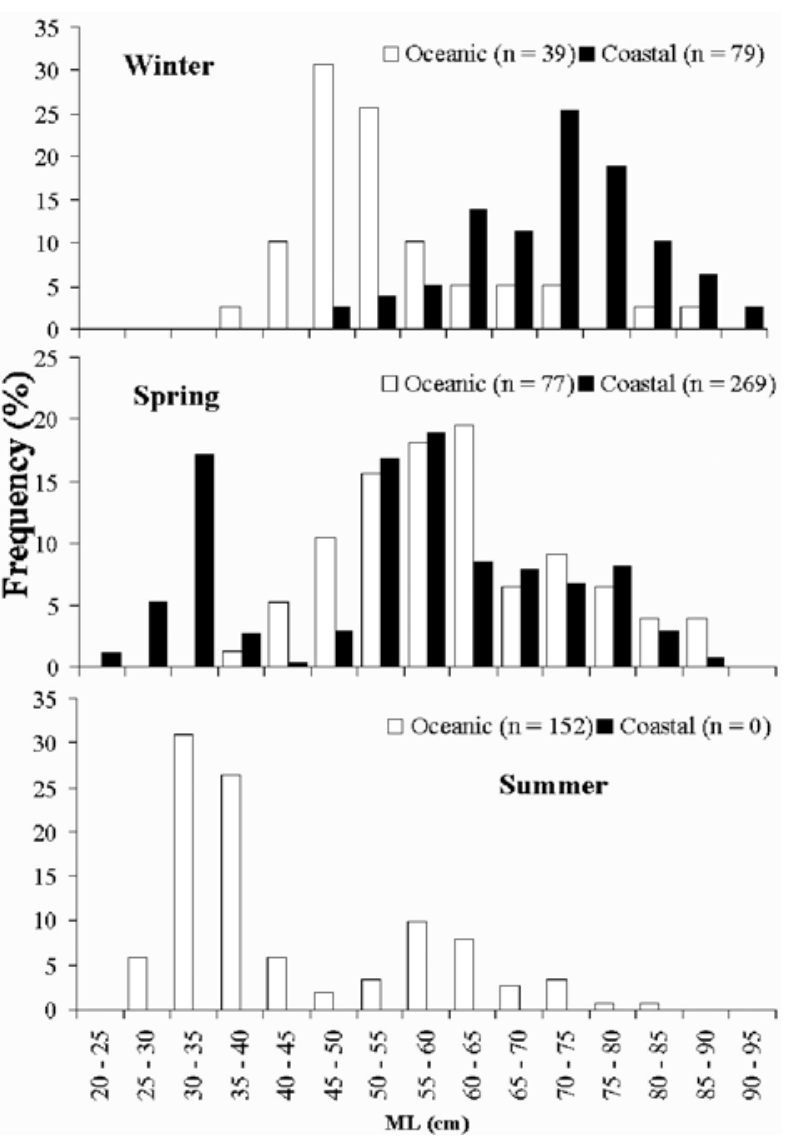

FIG. 3. - Length-frequency distributions of D. gigas in winter 2003, spring 2003, and summer 2004 (Southern hemisphere). 
TABLE 3. - Frequency of sex maturity stages (\%) of D. gigas in oceanic and coastal sectors in winter 2003, spring 2003 and summer $2004(\mathrm{n}=$ number of individuals $)$

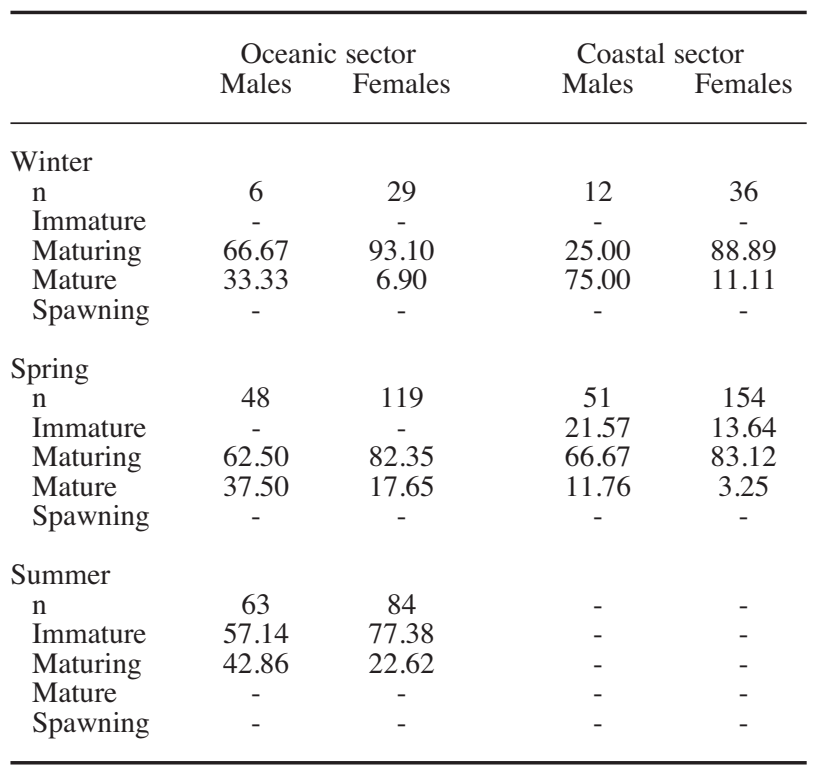

males and 32 females. The length-frequency was significantly different between coastal and oceanic sectors in winter (Dmax $=0.58 ; \mathrm{p}<0.001)$ (Fig. 3).

In spring, 269 individuals of $D$. gigas were obtained in the coastal sector (67 males, 162 females, and 40 undetermined). In the oceanic sector, $77 \mathrm{spec}-$ imens consisting of 21 males and 56 females were collected. The sex ratio was similar, but the average length of the oceanic specimens was larger than that of the coastal specimens (Table 2). In the coastal sector, a group of small individuals ( $<40 \mathrm{~cm} \mathrm{ML)} \mathrm{gener-}$ ated significant differences between zones (Dmax $=$ $-0.57, \mathrm{p}<0.001$ ) (Fig. 3). In summer, 152 individuals were captured in the oceanic zone, where 63 were males, 84 females and 5 undetermined, with a sex ratio of 1.3:1, an average size of $43.3 \mathrm{~cm}$ ML (range: $28-84 \mathrm{~cm}$ ) and an average weight of $3.4 \mathrm{~kg}$ (range: $0.47-17.6 \mathrm{~kg}$ ). In this season and sector, immature individuals $(<40 \mathrm{~cm}$ ML) dominated the length-frequency distribution (Fig. 3).

In winter, the frequency of sexual maturity stages of $D$. gigas differed between sexes in the coastal sector $\left(\chi^{2}=17.26\right.$, d.f. $\left.=3, \mathrm{p}=0.0006\right)$, where a large proportion of mature males (with spermatophores) were found as compared with females. In the oceanic sector, the frequency of maturity stages was similar in males and females $\left(\chi^{2}=3.88\right.$, d.f. $=3, p=0.275$ ), although a larger proportion of maturing individuals was observed for both sexes (Table 3).

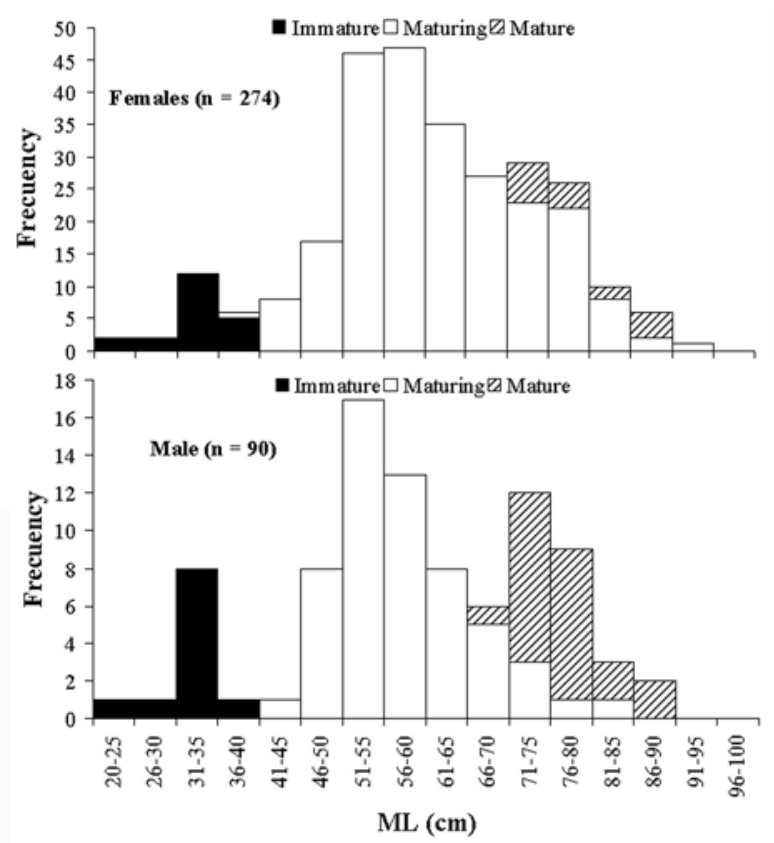

FIG. 4. - Frequency of maturity stages, by mantle length class, for a) females and b) males.

In spring, the frequency distribution of maturity stages of D. gigas was similar for males and females in the coastal sector $\left(\chi^{2}=7.81\right.$, d.f. $\left.=3, p=0.05\right)$, where immature specimens were observed (Table $3)$. In the oceanic sector, a higher proportion of the maturing animals was present, with few mature individuals, for both sexes. There was no significant difference between sexes in the distribution of maturity stages $\left(\chi^{2}=7.55\right.$, d.f. $\left.=3, p=0.05\right)$.

In summer, the frequency distribution of maturity stages was similar between sexes $\left(\chi^{2}=6.79\right.$, d.f. $=3, \mathrm{p}=0.07)$, although characterised by a higher proportion of immature females than males. No mature individuals were observed (Table 3).

Considering the whole period, immature females and males ranged between 20 and $40 \mathrm{~cm} \mathrm{ML}$, maturing females between 40 and $95 \mathrm{~cm}$ ML and males between 41 and $85 \mathrm{~cm} \mathrm{ML}$, while mature females and males ranged between 70 and $90 \mathrm{~cm}$ ML (Fig. 4).

\section{DISCUSSION}

The parameters of the length-weight relationships were similar to those found by Chong et al. (2005) for central-north Chile in 1993. The average weight of females was heavier than that of males at a given length, a difference that starts to be evident in specimens larger than $50 \mathrm{~cm}$ ML. Markaida 
(2001) found similar results for jumbo squid in the Gulf of California, but the average weight of jumbo squid in the central-south area off Chile seems to be greater than that of specimens of the Gulf of California, particularly in larger squids.

The evidence shown in this paper suggests that $D$. gigas in central-south Chile shows large spatial and seasonal changes in the length structure. Nevertheless, the changes observed in the length structure could be associated with the selectivity of the different fishing gears used. In fact, the samples obtained in oceanic waters come from the by-catch of the Trachurus murphyi purse-seine fishery, while most of the samples in the coastal sector are from the by-catch of mid-water trawl fisheries. Unfortunately, we do not have simultaneous samples of the fishing gears operating within the same sector to test for significant differences. Nevertheless, in spring and summer both fishing gears were able to catch smaller specimens with a mode in $35 \mathrm{~cm}$ ML, while the size structure of specimens larger than $45 \mathrm{~cm}$ was similar between coastal and oceanic sectors in spring (Fig. 3 ). Therefore, we think that selectivity of the different fishing gear is not an important factor in determining changes in the length structure. Rather, we think that the observed changes could be related to probable migrations of jumbo squid between oceanic and coastal sectors off Chile, as well as to the reproductive strategy of the species off Chile. Also, the changes observed in the length structure could be related to active feeding migrations or invasions from the northern part into the peripheries of the austral range of the species (Nigmatulling et al., 2001).

In winter, we found a maturing group of medium-size specimens (mode: $45-50 \mathrm{~cm}$ ML) in the oceanic zone, while in the coastal zone a second large-size group (mode: $70-75 \mathrm{~cm} \mathrm{ML}$ ) was found, with an important proportion of maturing females and also of mature males. In both zones, males were mature. In spring, medium-sized and large-sized groups overlapped in the oceanic zone, and maturing specimens were found. In the coastal zone, two size groups were observed in spring: one consisting of immature individuals with a mode of $30-35 \mathrm{~cm}$ ML and one consisting of large-sized and maturing individuals. In spring and summer, the presence of smaller specimens with a mode of $30-35 \mathrm{~cm}$ ML as well as the medium-sized specimens with a mode of 55-65 cm ML could suggest the occurrence of two spawning seasons during the annual cycle off central-south Chile, and therefore the generation of an average of two cohorts per year. The pooled lengthfrequency data suggests the presence of a local population of D. gigas in central-south Chile, which is structured by size.

However, evidence of post-spawning specimens was not found during the study period. According to Nigmatullin et al. (2001), spawning should occur from October to January in the southern hemisphere, or from December to May as in Peru (Clarke and Paliza, 2000; Argüelles et al., 2001). Although we found mature specimens larger than $70 \mathrm{~cm}$ (female) and $65 \mathrm{~cm}$ (males), we are not able to confirm the existence of a spawning season during spring and summer. Unfortunately our data are limited, and the hypothesis that the seasonal changes in the length structure are associated with the presence of two cohorts per year should be tested in the future. The spawning of $D$. gigas probably takes place outside the study area, and the seasonal changes observed in the length structure could be more related to an active feeding migratory strategy of the species in the study area. Moreover, post-spawning ommastrephid squids are rarely observed in fishing catches because they stop feeding (Markaida and SosaNishizaki, 2001).

The migratory strategy of D. gigas off Chile, related to spawning and feeding processes, is far from clear. However, according to Nesis (1970) and Nigmatullin et al. (2001), the complex population structure could be due to horizontal migrations between feeding and reproductive areas. One might assume that the smaller jumbo squid tend to leave the coastal zone in summer, migrating towards the oceanic zone to avoid predation and enhance the survival of their offspring. D. gigas is a short-lived and fast growing species (Argüelles et al., 2001; Markaida et al., 2004), and once the juveniles are able to attain larger sizes they could migrate into the coastal zone (continental shelf) to feed during autumn and winter, and to spawn on the continental slope and in adjacent oceanic areas as in Peru. This migratory strategy could be more evident during periods of high abundance such as that which has occurred recently.

\section{ACKNOWLEDGEMENTS}

L.C. thanks the "Subsecretaría de Pesca" for authorising the fishing research and the landing of jumbo squid for the fishing fleet participating in this 
research. We thank M. Gallardo, E. Cid, J. Garrido, A. Vera, R. Mena, R. Torres, C. Vera, C. Capponi and $\mathrm{C}$. Bruno for their assistance in sampling on board and at the main landings locations, as well as in the laboratory analysis. We thank C.M. Nigmatullin for comments and review of an early version of this paper. We are also grateful for the suggestions and recommendations of two anonymous referees.

\section{REFERENCES}

Anderson, C.I.H. and P.G. Rodhouse. - 2001. Life cycles, oceanography and variability: ommastrephid squid in variable oceanographic environments. Fish. Res., 54: 133-143.

Argüelles J., P.G. Rodhouse, P. Villegas and G. Castillo. - 2001. Age, growth and population structure of the jumbo flying squid Dosidicus gigas in Peruvian waters. Fish. Res., 54: 51-61.

Chong, J., C. Oyarzún, R. Galleguillos, E. Tarifeño, R.D. Sepúlveda and C.M. Ibáñez. 2005. Parámetros biológico-pesqueros de la jibia, Dosidicus gigas (Orbigny, 1835) (Cephalopoda: Ommastrephidae) frente a la costa de Chile central $\left(29^{\circ} \mathrm{S}\right.$ y $40^{\circ} \mathrm{S}$ ) durante el periodo 1993-1994. Gayana, 69: 319-328.

Clarke, R., and O. Paliza. - 2000. The Humboldt Current squid Dosidicus gigas (Orbigny, 1835). Rev. Biol. Mar. Ocean., 35: 1-39.

Fernández, F. and J.A. Vásquez. - 1995. La jibia gigante Dosidicus gigas (Orbigny, 1835) en Chile: análisis de una pesquería efímera. Est. Ocean., 14: 17-21.

Lipiñski, M.R. and L.G. Underhill. - 1995. Sexual maturation in squid: quantum or continuum? S. Afr. J. Mar. Sci., 15: 207-223.

Markaida, U.A. - 2001. Biología del calamar gigante Dosidicus gigas Orbigny, 1835 (Cephalopoda: Ommastrephidae) en el golfo de California, México. Ph. D. thesis. Centro de Investigación Científica y de Educación Superior de Ensenada, Ensenada, Baja California, México.

Markaida, U. and O. Soza-Nishizaki. - 2001. Reproductive biology of jumbo squid Dosidicus gigas in the Gulf of California, 19951997. Fish. Res., 54: 63-82.

Markaida, U., C. Quiñónez-Velásquez and O. Soza-Nishizaki. 2004. Age, growth and maturation of jumbo squid Dosidicus gigas (Cephalopoda: Ommastrephidae) from the Gulf of California, Mexico. Fish. Res., 66: 31-47.

Nesis, K.N. - 1970. The biology of the giant squid of Peru and Chile, Dosidicus gigas. Okeanology, 10: 140-152.

Nigmatullin, Ch.M., K.N. Nesis and A.I. Arkhipkin. - 2001. A review of the biology of the jumbo squid Dosidicus gigas (Cephalopoda: Ommastrephidae). Fish. Res., 54: 9-19.

Rocha, F. and V.M. Vega. - 2003. Overview of the cephalopod fisheries in Chilean waters. Fish. Res., 60: 151-159.

Roper, C., J. Sweeney and C. Nauen. - 1984. Cephalopods of the world (FAO species catalogue (vol 3), an annotated and illustrated catalogue of species of interest to fisheries. FAO Fish. Synop., 3(125): 1-127.

Schmiede, P. and E. Acuña. 1992. Regreso de las jibias (Dosidicus gigas) a Coquimbo. Rev. Chil. Hist. Nat., 65: 389-390.

Tafur R., P. Villegas, M. Rabí and C. Yamashiro. - 2001. Dynamics of maturation, seasonality of reproduction and spawning grounds of the jumbo squid Dosidicus gigas (Cephalopoda: Ommastrephidae) in Peruvian waters. Fish. Res., 54: 33-50.

Taipe, A., C. Yamashiro, L. Mariategui, P. Rojas and C. Roque. 2001. Distribution and concentrations of jumbo squid (Dosidicus gigas) off the Peruvian coast between 1991 and 1999. Fish. Res., 54: 21-32.

Wilhelm, O. - 1951. Algunas observaciones acerca de las mortandades de jibias (Dosidicus gigas D' Orb.) en el litoral de Concepción. Rev. Biol. Mar., 4: 196-201.

Zar, J.H. - 1984. Biostatistical analysis. Second edition. PrenticeHall, Inc. New York.

Received February 24, 2006. Accepted October 19, 2006.

Scient. ed.: G. Pierce.

Published online February 26, 2007. 